\title{
Film Device
}

National Cancer Institute

\section{Source}

National Cancer Institute. Film Device. NCI Thesaurus. Code C49955.

A photographic material designed to capture an image upon exposure to electromagnetic radiation. 